Florida International University FIU Digital Commons

FCE LTER Journal Articles

FCE LTER

6-2014

\title{
Relating Freshwater Flow with Estuarine Water Quality in the Southern Everglades Mangrove Ecotone
}

\author{
Henry O. Briceño \\ Southeast Environmental Research Center, Florida International University, bricenoh@fiu.edu \\ Gabriel Miller \\ Everglades Foundation
}

Stephen E. Davis III

Everglades Foundation

Follow this and additional works at: https://digitalcommons.fiu.edu/fce_lter_journal_articles

Part of the Ecology and Evolutionary Biology Commons

\section{Recommended Citation}

Briceno, H.O., G. Miller, S.E. Davis. 2013. Relating freshwater flow with estuarine water quality in the southern Everglades mangrove ecotone. Wetlands DOI: 10.1007/s13157-013-0430-0

This material is based upon work supported by the National Science Foundation through the Florida Coastal Everglades Long-Term Ecological Research program under Cooperative Agreements \#DBI-0620409 and \#DEB-9910514. Any opinions, findings, conclusions, or recommendations expressed in the material are those of the author(s) and do not necessarily reflect the views of the National Science Foundation. This work is brought to you for free and open access by the FCE LTER at FIU Digital Commons. It has been accepted for inclusion in FCE LTER Journal Articles by an authorized administrator of FIU Digital Commons. For more information, please contact dcc@fiu.edu, jkrefft@fiu.edu. 


\section{Introduction}

As has been the case with many wetland ecosystems around the globe, the Everglades has endured more than a century of drainage, reduced water flow, agricultural pollution, and urban development (Mitsch \& Gosselink 2009). With increased understanding of the value of wetland ecosystems over the past few decades, we have seen a shift towards restoration and conservation of these remaining landscapes. Today, the greater Everglades ecosystem represents one of the largest ecosystem restoration undertakings in the world. As such, it provides an ideal opportunity for scientists to develop, apply, and adapt tools for projecting ecological change in response to different restoration (and even climate change) scenarios (Clark et al. 2001).

South Florida and the Everglades were once synonymous as a mosaic of hydrologically interconnected landscapes and communities comprising the largest single marsh system in the United States (Ogden et al 2005). Today, remaining subtropical wetlands and their drainages are disconnected, over-drained, and managed by a complex network of canals $(2,300 \mathrm{Km})$ and structures. As a result, there has been extensive soil loss due to subsidence and peat oxidation, an increase in algal bloom frequency and magnitude, decreases in bird and mammal populations, shifts in vegetative community structure, and saltwater intrusion (Lorenz, 1999; Sklar et al., 2001; Marshall et al. 2009).

In Everglades National Park, located at the southernmost tip of the Florida

Peninsula, decreased flow and increased nutrient loading (especially phosphorus), can lead to loss of periphyton — the base of the Everglades food web—and irreversible 
change in vegetative community structure, both of which lead to diminished habitat

2 quality (Davis, 1994; McCormick et al. 1996; Childers et al., 2001; Durako et al., 2001;

3 Gaiser et al., 2004). Therefore restoring the natural flow and quality of water to the

4 Everglades is critical to protecting the remaining "River of Grass", mangrove forests, 5 and estuaries such as Florida Bay.

To date, few modeling or quantitative tools exist to help us understand how restoring the quantity and quality of flows to Florida Bay will affect its health. This is partly due to the complexity of these dynamic coastal environments and difficulty in accurately predicting ecosystem behavior-let alone responses to different management decisions (Stow et al. 2003). Marshall et al. (2011) recently developed a set of multi-variate linear regression models that link Everglades stage and regional climatic conditions to salinity. When coupled to habitat suitability indices developed for species such as Roseate spoonbills (Ajaja ajaja; Lorenz 1999) and the American crocodile (Cocodrylus acutus; Green et al. 2001), these tools can be effective in projecting habitat improvement with hydrologic restoration. However, there are currently no means for projecting change in other water quality parameters, such as nitrogen or phosphorus that affects the productivity and carbon dynamics in the mangrove ecotone. This is particularly important given the progress of restoration in the C-111 canal basin of south Florida and the continual press of sea-level rise.

The C-111 provides flood control for much of southeast Miami-Dade County. Its effectiveness in flood control is equaled by its impact on Florida Bay, as it not only drains much of the developed landscape in South Florida, it also siphons water away from Taylor Slough—the most important source of freshwater to eastern Florida Bay 
1 (Figure 1). The seepage barrier of the C-111 Spreader Canal project, a Comprehensive

2 Everglades Restoration Program (CERP) project, has recently become operational and will serve to minimize water loss from Taylor Slough to the C-111 canal drainage system. Phase 2 of this effort, will eventually result in the filling-in of this canal and will restore natural flows of freshwater into Florida Bay.

In anticipation of these restoration efforts, we utilized statistical techniques to

7 understand the relationships between flow and water quality in this region of Everglades

8 National Park. Such relationships are difficult to detect with naturally high variability in

9 water quality data as well as the confounding effects of natural versus human-induced control over water flow in this region. Specifically, we sought to determine the relationships between salinity, nutrients, and flow in the mangrove ecotone of lower

12 Taylor Slough. The motivation for this is that the restoration of flows into Taylor Slough and the $\mathrm{C}-111$ basin will result in substantially increased flows of freshwater to Florida

\section{Site Description}

Taylor Slough is located in Everglades National Park and functions as the

22 southeastern watershed that historically channeled water from the Everglades to Florida 
1 Bay (Figure 1). Along with Shark River Slough, it is one of the most important

2 watersheds in Everglades National Park, and it is of vital importance to the overall

3 health of the park—especially Florida Bay. The southern Everglades mangrove

4 ecotone lies at the interface between the freshwater Everglades marshes of lower

5 Taylor Slough and eastern Florida Bay and one of the major distributaries of flow along

6 this path is Taylor River (Figure 1).

Two sites were considered in this analysis: the Taylor River mouth site and the Taylor River upstream site (Figure 1). The Taylor River mouth site exhibits a daily tidal

9 range of about $10 \mathrm{~cm}$ or less. The daily tidal signature at the upstream site is considerably more muted. Inputs of water to this ecotone are primarily from direct

11 precipitation, local runoff, releases from water-management structures, and tidal flow

12 from the Florida Bay into the ecotone, and flow direction and magnitude at both sites

13 are influenced by seasonal discharge from the freshwater Everglades, wind, and storm 14 events.

The salinity and nutrient dynamics of this mangrove ecotone illustrate fundamental ecosystem responses to the natural seasonal rainfall pattern but also to

17 the imposed (i.e., managed) hydrological regime (Rudnick et al. 1999; Sutula et al., 18 2003). Nutrient exchange in Taylor Slough affects the water quality of Florida Bay and 19 therefore, the Florida Keys (Lapointe et al., 2001). Taylor Slough, as part of the 20 Everglades, is considered an oligotrophic environment such that-in its natural state21 has very low nutrient availability and efficient biogeochemical cycles (Noe et al., 2003;

22 Childers et al., 2006). As a result, oligotrophic Everglades wetlands are particularly 
1 vulnerable to invasion and habitat transformation if additional nutrients are loaded

2 (Davis 1994; McCormick et al., 1996).

3 Taylor Slough currently operates in a diminished hydrologic capacity, largely due

4 to a reduced watershed and its proximity to agriculture, given the reduced groundwater

5 levels legally mandated during the fall and early winter produce-growing season,

6 precisely during the natural times for highest freshwater flows (Oct-Nov). The

7 downstream consequence of diminished flow has been increased salinity in parts of the

8 mangrove ecotone and Florida Bay resulting in loss of habitat and reduced density of

9 pink shrimp and wading birds in Florida Bay (Robblee et al., 1991; Mclvor et al., 1994;

10 Lorenz 1999; Brand 2001). In turn, this has led to the landward expansion of the 'white

11 zone'-a low productivity zone between the mangrove ecotone and the sawgrass-

12 dominated landscape of the southern Everglades-by about 1.5 kilometers between

131940 and 1994 (Ross et al., 2001).

The major direct agent that has altered the hydrology of Taylor Slough is the C-

15111 canal, which siphons water away from Taylor Slough and routes it into lower Biscayne Bay/Manatee Bay (via the S-197 structure) and far eastern Florida Bay (Light

17 and Dineen, 1994). As such, restoration efforts are centering on the C-111 canal to

18 increase freshwater flow into Taylor Slough, thus returning the timing of the flows to a

19 semblance of its natural state. The seepage barrier component of the C-111 Spreader

20 Project will create a hydrological head in the surrounding area, keeping more water in

21 Taylor Slough and allowing for more of that freshwater to enter into Florida Bay

22 (USACE, 2011). 


\section{Methods}

3 Data Sources and Analyses

$4 \quad$ Discharge data for the Taylor River mouth and Taylor River upstream sites came

5 from the USGS (http://fl.water.usgs.gov/Miami/hurricane/) and water quality data were

6 derived from the Florida Coastal Everglades Long-Term Ecological Research (FCE-

7 LTER) program ( http://fcelter.fiu.edu/data/core/). Water quality parameters included

8 total nitrogen (TN), total phosphorus (TP), and salinity values. Sampling intervals were

9 tri-daily from Jan 1996 to Sept 2009 (POR). Unfiltered water samples were analyzed for

10 total nitrogen (TN) and total phosphorus (TP). TN was measured using an ANTEK

$117000 \mathrm{~N}$ Nitrogen Analyzer using $\mathrm{O}_{2}$ as carrier gas to promote complete recovery of the

12 nitrogen in the water samples (Frankovich and Jones 1998). TP was determined using

13 a dry ashing, acid hydrolysis technique (Solórzano and Sharp 1980). Data sets were

14 manipulated to remove null data points and discharge data was 3-day averaged to

15 match the intervals of the FCE LTER water quality sampling program.

Cumulative sum charts

We used statistical techniques developed primarily for industrial processes

19 (standardized cumulative sum) to envision linkages between four base variables:

20 salinity, total phosphorus (TP) and total nitrogen (TN) concentrations, daily discharge,

21 and the ratio of total nitrogen (TN) to total phosphorus (TN:TP), a key indicator of the 
1 biological availability of these ecologically important nutrients. In doing so, we sought to

2 predict the direction and likely consequences of hydrologic restoration of the Taylor

3 Slough ecosystem through the implementation of the $\mathrm{C}-111$ spreader project.

We explored the structure of time-series to identify and characterize their

5 components (trend, cycles and seasonality) with standardized cumulative sum charts

6 (Cusum; Manly and MacKenzie 2000). A standardized Cusum chart is a plot of the

7 cumulative sum of standardized deviations from a target specification (in our case the

8 time-series grand mean), against $n$, the sample number (or date if regularly sampled)

9 (Ewan, 1963). Standardization is performed as follows:

$$
z_{i}=\left[\left(x_{i}-m\right) / \sigma\right]+z_{i-1} ; m=\text { mean and } \sigma=\text { standard deviation }
$$

As such, the Cusum procedure sums up the deviations around the mean and provides a visual representation of smoothed data used to infer trends or change points

14 in a time series. The key elements in Cusum charts are the slopes and slope breaks.

15 We should keep in mind that interpretation of Cusum line-plots is different from the usual interpretation of scatter-plots. A segment with a positive slope in the Cusum graph

17 represents a period where most of the values in the original series $\left(\mathrm{x}_{\mathrm{i}}\right)$ are aboveaverage, and not necessarily that values are increasing, as we usually interpret positive slopes in scatter-plots. Segments with negative slopes in Cusum space indicate belowaverage values (not necessarily an indication of a decline in the original series).

21 Likewise, horizontal segments in the Cusum represent average conditions. Finally, 22 monotonically increasing secular trends in the dataset produce positive parabolic 
1 Cusum curves (cup- or V-shape) and monotonically decreasing trends produce negative

2 parabolic curves (dome- or peak-shape).

3 Cusum charts and Cusum analysis are standard procedure in the field of

4 industrial process control (Duncan 1974; Grant and Leavenworth 1980; Montgomery

5 2001), and the direct connection between Cusum and process performance, has driven

6 increasing applications to the earth sciences, especially for the analysis of time-series

7 data in oceanography, geology, climate change and ecology (Ibanez et al. 1993; Adrian

8 et al. 2006; Molinero et al. 2008; Briceño and Boyer 2010; Wachnicka et al. 2013),

9 especially when identifying cause-effect (driver-response) relationships. In our case,

10 Cusum analyses were first run to identify temporal changes in salinity, nutrients (TN and

11 TP), and discharge time series. Then, Cusum charts were used to assess changes in

12 TN, TP, salinity and TN:TP molar ratios relative to discharge gradients.

\section{Results}

The mouth of Taylor River is considerably more saline and influenced by tide and wind-driven shifts in discharge compared with the upstream site (Table 1). Both Taylor

17 River sites exhibited similar TP concentrations, but median TN concentrations were about $4 \mu \mathrm{M}$ higher at the mouth site compared with the upstream site during the period of record (7/30/99 to 9/30/09). This is reflected in slightly higher TN:TP ratios at the 20 mouth site (Table 1). 
1 2003; Childers et al. 2006). Considering hydrologic conditions at Taylor River mouth

2 and using this as a surrogate for conditions throughout the region, we found a clear

3 seasonal pattern of discharge coinciding with wet season rainfall that begins in late

4 May/early June and typically runs through November (Figure 2a). Mean daily stage in

5 Taylor River corresponded with this (Figure 2b), likely as a result of upland runoff

6 backing up against the Buttonwood Ridge-a sediment embankment running along the

7 interface between the mangrove ecotone and eastern Florida Bay. As expected, salinity

8 at Taylor River mouth is inversely related to discharge, with lowest values in the wet

9 season and highest values at the height of the dry season in May (Figure 2c). However,

10 surface water TP concentrations, which are variable throughout the year, seemed to

11 track salinity with highest minimum and median concentrations occurring at the peak of

12 the dry season (Figure 2d).

Temporal trends

Cusum charts were constructed by plotting standardized cumulative data for

16 each variable along the $y$-axis, and time on the $x$-axis (see panels in Figure 3 ). Results

17 show that rainfall at NOAA's Everglades Station (Figure $3 a$ and $3 b$ ) and discharge

18 (Figure 3c and 3d) follow similar patterns until mid 2005, with discharge lagging rainfall

19 by about 1-3 months. Relative low discharges prevailed until June 1997 (steep negative

20 slope), then a more obvious seasonal pattern with two 4-year cycles were experienced,

21 followed by a strong departure towards high discharges during the 2005 hurricane

22 season (i.e., Katrina, Rita, Wilma). Since then, we have seen a seasonal pattern of 
1 discharge superimposed on a below-average discharge tendency (Figure 3d), while

2 rainfall follows an above-average tendency. Salinity exhibited a long-term increasing

3 secular trend (Figure 3e; also note cup-shaped cusum in Figure 3f) in which well-

4 defined seasonal cycles were superimposed (Figure $3 e$ and $3 f)$. For this record, salinity

5 was below-average until early 1999 when an average tendency began and remained as

6 such until 2001. It was followed by a below-average tendency until March 2004 (Figure

7 3f). Since then the general tendency has been one of above-average salinity values

8 (>15.5 ppt). Concentrations of TN were relatively high until 2003, exhibiting two similar

9 cycles of below-average to above-average values within that period (Figure $3 g$ and $3 h$ ).

10 After 2003, low TN prevailed at Taylor River mouth until early 2008. Since then TN has

11 increased to above-average levels (Figure 3h). On the other hand, total phosphorus

12 (TP; Figures $3 i$ and $3 j$ ) showed irregular seasonal patterns until late 2000 when a

13 sustained low TP period began, and lasted until the end of 2005 (Figure 3j). Since

14 January 2006 TP concentrations have been relatively high. Relating these patterns of

15 change in TN to TP, the TN:TP molar ratio experienced irregular oscillations until

16 September 2000 , followed by a significant departure towards high values (TN:TP=342)

17 from October 2000 to April-2003 (Figure 3k and 3I). After a short period of close to

18 average tendency (TN:TP=224), which extended to mid 2004, there was a sustained

19 decline of TN:TP (=158) lasting until early 2009.

20

21

Discharge gradients 
Slopes of ordinary linear regressions of salinity, TP, TN and TN:TP on discharge were calculated to estimate secular trends along discharge gradients (Table 2). Most slopes are statistically significant at $p<0.10$, except TN at upstream Taylor and TN:TP at

4 Taylor Mouth.

5 Taylor River upstream:

As expected, salinity at the Taylor River upstream site was negatively correlated with discharge showing a clear declining secular trend (i.e., dome-shaped cusum;

8 Figure 4a). The inflexion point for salinity, from below-average to above-average salinity occurred at $0.17 \mathrm{~m}^{3} / \mathrm{s}$. Cusum trend results for TN at the upstream site had two important breaks, which highlight the non-linear response of TN to discharge at this less

11 tidally-influenced site: from below-to-above average TN at about $-0.18 \mathrm{~m}^{3} / \mathrm{s}$, and from

12 above-to-below average at $0.30 \mathrm{~m}^{3} / \mathrm{s}$ (Figure 4b). Hence, very low TN concentrations

13 prevailed during negative flows (e.g., during strong southerly wind or tidal events) as

14 well as during extreme positive flows (e.g., wet season discharge events). TP exhibited

15 a marked declining secular trend with increasing discharge (note clear dome-shaped correlation between TP and discharge, ratios at the upstream site seemed to be driven 
1 TN:TP values occurred below $0.11 \mathrm{~m}^{3} / \mathrm{s}$, and above-average TN:TP occurred for

2 discharges above $0.25 \mathrm{~m}^{3} / \mathrm{s}$.

3 Taylor River mouth:

$4 \quad$ At the mouth of Taylor River, salinity declined with discharge and the inflexion

5 point for above-to-below average salinity (13.46 ppt) occurred at $0.80 \mathrm{~m}^{3} / \mathrm{s}$ (Figure $4 \mathrm{e}$ ).

6 TN and TP cusum patterns versus discharge were non-linear and similar up to $0.7 \mathrm{~m}^{3} / \mathrm{s}$

7 discharge (Figure $4 \mathrm{f}$ and $4 \mathrm{~g}$ ). When considered separately, negative flows produced an

8 increasing trend of TN and TP as discharge approached zero but overall below-average

9 TN and TP concentrations of 54.5 and $0.33 \mathrm{uM}$, respectively. Between zero and 0.70

$10 \mathrm{~m}^{3} / \mathrm{s}$ discharge TN and TP concentrations increased to 60.1 and $0.36 \mathrm{uM}$ respectively.

11 Larger discharges resulted in TP decline to a mean of $0.31 \mathrm{uM}$. On the other hand, TN

12 declined to $52.1 \mathrm{uM}$ at discharges between 0.7 and $1.12 \mathrm{~m}^{3} / \mathrm{s}$. Beyond that, TN

13 increased to $60.3 \mathrm{uM}$ between 1.12 and $1.18 \mathrm{~m}^{3} / \mathrm{s}$ and finally declined to an average of

$1452.9 \mathrm{uM}$ for higher discharges (Figure 4f). The correlation coefficient for a power

15 regression model between TP and TN:TP is 0.71 , while the best for TN versus TN:TP is

16 0.15. Hence, although TN and TP cusum patterns are similar to TN:TP at the mouth

17 site, TP seems to drive much of the discharge-related fluctuations in TN:TP ratios at

18 the mouth site during the period of record (Figure 4h).

20 Discussion

21 Variations in tidal creek flow are known to affect patterns of estuarine water

22 quality (Eyre and Balls 1999); however, these patterns can be greatly modified by short- 
1 term storm events, longer term variations in climate, and interactions with human

2 activities (Childers et al. 1990; Paerl et al. 2006). This confounds our ability to

3 effectively predict water quality fluctuations in sensitive coastal waters subjected to a

4 range of natural and human-related drivers. The descriptive statistical approach we

5 used, combined with evidence observed by others, can help establish the link between

6 flow of water from Taylor Slough, phosphorus and nitrogen dynamics, and TN:TP ratios

7 in the southern Everglades mangrove ecotone. Once those relationships are

8 established, we can begin to unravel the effects of water management, restoration,

9 climatic, and event-driven dynamics.

The period around 2004-2005 marked a series of distinct water quality changes

11 at these sites (Figure 3; e.g., increase in salinity, decline in TN, increase in TP, and

12 decline in TN:TP ratio). This is noteworthy, as it was a period of time marked by two very active hurricane seasons, and there is ample evidence showing that water quality,

14 hydrology and sediment dynamics of this region are greatly influenced by such storm events (Davis et al. 2004; Woods and Zucker, 2007; Castañeda-Moya et al., 2009; Briceño and Boyer 2010). Furthermore, these trends gradually reverted to previous conditions by 2009, indicating the lasting effects of these types of events (Figure 3; e.g., Paerl et al. 2006). In south Florida, these lasting impacts are to be expected given the 19 large volumes of seawater and P-rich marine/bay sediments brought to the mangrove

22 hydrologic conditions affecting discharge and salinity, with highest TP concentrations 
1 ppt). This seemed clearest at the upstream site, where Everglades runoff and internal

2 processes have prevailing control over nutrient availability. High TP under these low

3 flow conditions may result through a number of processes including increased

4 discharge of relatively high TP groundwater (Price et al. 2006), increased influence of

5 the relatively high TP marine end-member (Childers et al. 2006), evaporative

6 concentration of TP, or a decreased demand for surface water TP due to labile C

7 limitation resulting from high hydrologic residence times (as suggested by Davis and

8 Childers 2007). This supports findings from other water quality studies in this region

9 indicating that increased freshwater flows from the C-111 will not only reduce

hypersalinity events in the bay but will also lower surface water TP concentrations in the

11 mangrove ecotone, thus contributing to a restoration of the oligotrophic character of this

12 region.

Nitrogen dynamics are more complicated and perhaps indicate the influence of

14 both external and internal sources of TN at different times of the year. Further, evidence suggests that the Everglades mangrove ecotone may be a hot spot for nitrogen dynamics driven by high organic matter accumulation and $\mathrm{N}$ immobilization

17 (Rivera-Monroy et al. 2011). Relating flows and water quality, Davis et al. (2003) and

18 Childers et al. (2006), respectively, suggested that a positive relationship between

19 freshwater flow and TN concentrations reflected a possible upland source (i.e., freshwater marsh) of TN or an internal mangrove source (i.e., mangrove) of TN in

21 response to wet season onset. An analysis of limited flux data from within the

22 mangrove ecotone indicated a net release of $\mathrm{TN}$ from the mangrove to the water

23 column at salinity values above about 27 ppt (Davis et al. 2003). More recent flux data 
1 by Liu and Davis (this issue) indicate consistent low-level soil/sediment uptake of nitrate

$2+$ nitrite in combination with high-level release of ammonium in different ecotone

3 habitats. The imbalance between these fluxes combined with seasonal re-wetting of the

4 upstream marsh may represent a significant source of TN in this region driving up ratios

5 of TN:TP early in the wet season.

6

7

In general, our approach showed that TN varied more over annual to inter-annual scales relative to TP that, despite exhibiting variation over longer time-scales, also showed a clearer relationship with seasonal discharge. Still, there were ranges of high discharge, perhaps at the outset of the wet season, when high discharge corresponded with high TN. This only speaks to the complex array of drivers affecting TN in this region and that more biogeochemical work needs to be done to understand nitrogen dynamics across the mangrove ecotone of Taylor Slough.

The Taylor Slough and C-111 restoration efforts are predicted to restore up to $87 \%$ of natural volume of flows according to the U.S. Army Corps of Engineers' best restoration alternative (USACE 2011). Assuming that current C-111 discharges to the coast will be retained in the Taylor Slough and adjacent marsh below the C-111 canal (i.e., the "C-111 basin") with full C-111 restoration, we could see $10 \%$ or more freshwater flowing into eastern Florida Bay each year relative to current conditions. With restored flows, increased freshwater passing through Taylor Slough and the C-111 basin could reduce phosphorus concentrations in the mangrove ecotone by reducing potential terrestrial sources and by minimizing the periods of time where Florida Bay is actively inputting phosphorus into the ecotone (Rudnick et al., 1999; Price et al. 2006; Childers et al. 2006). This will also shorten hydrologic residence times, which may also 
1 minimize local evaporative concentration and decrease periods of possible labile $\mathrm{C}$

2 limitation in the water column.

As a result of these actions and advanced states of Everglades restoration, we could anticipate a restored oligotrophic status to the lower Taylor Slough area of the

5 Everglades. However, as we have shown, these assumptions may be too simplistic.

6 Restored oligotrophic status is certainly the goal, but ecosystem responses are not

7 linear and recent research suggests that elevated $\mathrm{P}$ availability and the associated

8 changes in ecosystem structure will remain for extended periods following flow

9 restoration (Herbert and Fourqurean 2008). This is due in part to the retention of $P$ in

10 sediments (Liu et al. this issue) of these strongly P-limited ecosystems that has

11 occurred in the recent past combined with future changes in the availability of $\mathrm{N}$ across

12 this ecotone. Further, it does not consider the continual effects of sea-level rise along

13 the vulnerable south Florida coastline.

Our approach presented here is useful in that it provides a tool for revealing

15 patterns, relationships, and change points in otherwise noisy water quality and hydrologic data. With the inclusion of more sites, longer time series, and process-

17 specific information on fluxes of $\mathrm{N}$ and $\mathrm{P}$, we hope to generate a better understanding of

18 long-term trends in water quality. This will allow us to link major climatic events and

19 cycles to regional hydro-ecological processes it will also be necessary to evaluate the

20 long-term benefits of restored flows in Taylor Slough and throughout the Greater

21 Everglades ecosystem. 


\section{Acknowledgements}

2 The authors thank the National Fish and Wildlife Foundation (grant \# 9934.12.029268)

3 and the Florida Coastal Everglades Long-Term Ecological Research program (National

4 Science Foundation cooperative agreements \#DEB-1237517 and DBI-0620409) for

5 their support of this research. The Everglades Foundation provided internship support

6 for G. Miller's work on this study. This is contribution \#608 from the Southeast

7 Environmental Research Center at Florida International University. 


\section{Literature Cited}

Adrian R, Wilhelm S, Gerten D (2006) Life-history traits of lake plankton species may govern their phenological response to climate warming. Global Change Biology 12:652-661

Brand LE (2001) The transport of terrestrial nutrients to South Florida coastal waters. In: Porter JW, Porter KG (eds) The Everglades, Florida Bay, and coral reefs of the Florida Keys: an ecosystem sourcebook. CRC Press, Boca Raton, Florida, pp 361-413

Briceño HO, Boyer JN (2010) Climatic controls on phytoplankton biomass in a subtropical estuary, Florida Bay, USA. Estuaries and Coasts 33:541-553 DOI 10.1007/s12237-009-9189-1

Castañeda-Moya E, Twilley RR, Rivera-Monroy VH, Zhang K, Davis SE, Ross M (2010) Sediment and nutrient deposition associated with Hurricane Wilma in mangroves of the Florida coastal Everglades. Estuaries and Coasts 33:45-58

Childers DL, Day JW JR, Muller RL (1990) Relating climatological forcing to coastal water levels in Louisiana estuaries and the potential importance of El NiñoSouthern Oscillation events. Climate Research 1:31-42

Childers DL, Jones RD, Trexler JC, Buzzelli C, Dailey S, Edwards AL, Gaiser EE, Jayachandaran K, Kenne A, Lee D, Meeder JF, Pechmann JHK, Renshaw A, Richards J, Rugge M, Scinto IJ, Sterling P, Gelder WV (2001) Quantifying the effects of low-level phosphorus additions on unenriched Everglades wetlands with in situ flumes and phosphorus dosing. In: Porter JW, Porter KG (eds) The Everglades, Florida Bay, and coral reefs of the Florida Keys: an ecosystem sourcebook. CRC Press, Boca Raton, Florida, pp 127-152

Childers DL, Boyer JN, Davis SE III, Madden CJ, Rudnick DT, Sklar FH (2006) Relating precipitation and water management to nutrient concentrations in the oligotrophic 
"upside-down" estuaries of the Florida Everglades. Limnology and Oceanography $51: 602-616$

Clark JS, Carpenter SR, Barber M, Collins S, Dobson A, Foley J, Lodge DM, Pascual M, Pielke R, Pizer W, Pringle C, Reid WV, Rose KA, Sala O, Schlesinger WH, Wall DH, Wear D (2001) Ecological forecasts: an emerging imperative. Science 293:657-660

Davis SM (1994) Phosphorus inputs and vegetation sensitivity in the Everglades. In: Davis SM, Ogden JC (eds) Everglades: the ecosystem and its restoration. St. Lucie Press, Delray Beach, Florida, pp 357-378

Davis SE, Childers DL, Day JW, Rudnick DT, Sklar FH (2003) Factors affecting the concentration and flux of materials in two southern Everglades mangrove wetlands. Marine Ecology Progress Series 253:85-96

Davis SE, Cable J, Childers C, Coronado C, Day JW, Hittle C, Madden C, Reyes E, Rudnick DT, Sklar FH (2004) Importance of episodic storm events in controlling ecosystem structure and function in a Gulf Coast estuary. Journal of Coastal Research 20(4):1198-1208

Davis SE, Childers DL (2007) Importance of water source in controlling leaf leaching losses in a dwarf red mangrove (Rhizophora mangle L.) wetland. Estuarine, Coastal, and Shelf Science 71(1-2):194-201

Duncan AJ (1974) Quality control and industrial statistics. Homewood: Richard D. Irwin.

Durako MJ, Hall MO, Merell M (2001) Patterns of change in the seagrass dominated Florida Bay hydroscape. In: Porter JW, Porter KG (eds) The Everglades, Florida Bay, and coral reefs of the Florida Keys: an ecosystem sourcebook. CRC Press, Boca Raton, Florida, pp 523-537

Ewan WD (1963) When and how to use Cu-sumcharts. Technometrics 5:1-32

Eyre BD, Balls P (1999) A comparative study of nutrient behavior along the salinity gradient of tropical and temperate estuaries. Estuaries 22:313-326 
Frankovich TA, Jones RD (1998) A rapid, precise, and sensitive method for the determination of total nitrogen in natural waters. Marine Chemistry 60:227-234

Gaiser EE, Scinto IJ, Richards JH, Jayachandran K, Childers DL, Trexler JC, Jones RD (2004) Phosphorus in periphyton mats provides the best metric for detecting lowlevel P enrichment in an oligotrophic wetland. Water Resources Research 38:507-516

Grant EL, Leavenworth RS (1980) Statistical quality control, 5th edn. New York: McGraw-Hill

Green TW, Slone DH, Swain ED, Cherkiss MS, Lohmann M, Mazzotti FJ, Rice KG (2001) Spatial and stage-structured population model of the American Crocodile for comparison of comprehensive Everglades restoration plan (CERP) alternatives. U.S. Geological Survey Open-File Report 2010-1284, 57 p

Ibanez F, Fromentin JM, Castel J (1993) Application of the cumulated function to the processing of chronological data in oceanography. Comptes rendus de l'Acade'́mie des Sciences, Serie 3(318):745-748

Herbert DA, Fourqurean JW (2008) Ecosystem structure and function still altered two decades after short-term fertilization of a seagrass meadow. Ecosystems 11:688700

Lapointe BE, Matzie WR Barile PJ (2001) Biotic phase-shifts in Florida Bay and fore reef communities of the Florida Keys: linkages with historical freshwater flows and nitrogen loading from Everglades runoff. In: Porter JW, Porter KG (eds) The Everglades, Florida Bay, and coral reefs of the Florida Keys: an ecosystem sourcebook. CRC Press, Boca Raton, Florida, pp 629-648

Light SS, Dineen JW (1994) Water control in the Everglades: a historical perspective. In: Davis SM, Ogden JC (eds) Everglades: the ecosystem and its restoration. St. Lucie Press, Delray Beach, Florida, pp 47-84 
Lorenz JJ (1999) The response of fishes to physicochemical changes in the mangroves of Northeast Florida Bay. Estuaries 22:500-517

Manly BFJ, Mackenzie D (2000) A cumulative sum type of method for environmental monitoring. Environmetrics 11:151-166

Marshall FE, Wingard GL, Pitts P (2009) A simulation of historic hydrology and salinity in Everglades National Park: coupling paleoecologic assemblage data with regression models. Estuaries and Coasts 32:37-53

Marshall FE, Smith DT, Nickerson DM (2011) Empirical tools for simulating salinity in the estuaries in Everglades National Park, Florida. Estuarine, Coastal, and Shelf Science 95: 377-387

Mccormick PV, Rawlik PS, Lurding K, Smith EP, Sklar FH (1996) Periphyton-water quality relationships along a nutrient gradient in the northern Florida Everglades. Journal of the North American Benthological Society 15:433-449

Mclvor CC, Ley JA, Bjork RD (1994) Changes in freshwater inflow from the Everglades to Florida Bay including effects on biota and biotic processes: a review. In: Davis SM, Ogden JC (eds) Everglades: the ecosystem and its restoration. St. Lucie Press, Delray Beach, Florida, pp 117-146

Mitsch, WJ, Gosselink JG (2007) Wetlands, $4^{\text {th }}$ Edition. John Wiley \& Sons, New York.

Molinero JC, Ibanez F, Souissi S, Buecher E, Dallot S, Nival P (2008) Climate control on the long-term anomalous changes of zooplankton communities in the Northwestern Mediterranean. Global Change Biology 14:11-26

Montgomery DC (2001) Introduction to statistical quality control, $3^{\text {rd }}$ Edition. John Wiley \& Sons, New York.

Noe GB, Childers DL, Edwards AL, Gaiser E, Jayachandran K, Lee D, Meeder J, Richards J, Scinto LJ, Trexler JC, Jones RD (2003) Short-term changes in phosphorus storage in an oligotrophic Everglades wetland ecosystem receiving experimental nutrient enrichment. Biogeochemistry 59:239-267 
Ogden JS, Davis S, Jacobs KJ, Barnes T, Fling H (2005) The use of conceptual ecological models to guide ecosystem restoration in South Florida. Wetlands 25(4):795-809

Paerl, HW, Valdes LM, Peierls BL, Adolf JE, Harding LW (2006) Anthropogenic and climatic influences on the eutrophication of large estuarine ecosystems. Limnology and Oceanography 51:448-462

Price RM, Swart PK, Fourqurean JW (2006) Coastal groundwater discharge - an additional source of phosphorus for the oligotrophic wetlands of the Everglades. Hydrobiologia 569:23-36

Rivera-Monroy VH, Twilley RR, Davis SE III, Childers DL, Simard M. Chambers R, Jaffe R, Boyer JN, Rudnick DT, Zhang K, Castañeda-Moya E, Ewe SML, Price RM, Coronado-Molina CR, Ross M, Smith TJ III, Michot B, Meselhe E, Nuttle W, Troxler TG, Noe GB (2011) The role of Everglades Mangrove Ecotone Region (EMER) in regulating nutrient cycling and wetland productivity in south Florida. Critical Reviews in Environmental Science and Technology 41(6):633-669

Robblee MB, Barber TR, Carlson PR, Durako MJ, Fourqurean JW, Muehlstein LK, Porter D, Yarbro LA, Zieman RT, Zieman JC (1991) Mass mortality of the tropical seagrass Thalassia testudinum in Florida Bay (USA). Marine Ecology Progress Series 71:297-299

Ross MS, Gaiser EE, Meeder JF, Lewin MT (2001) Multi-taxon analysis of the "White Zone," a common ecotonal feature of South Florida coastal wetlands. In: Porter JW, Porter KG (eds) The Everglades, Florida Bay, and coral reefs of the Florida Keys: an ecosystem sourcebook. CRC Press, Boca Raton, Florida, pp 205-238

Rudnick DT, Chen Z, Childers DL, Boyer JN, Fontaine TD III (1999) Phosphorus and nitrogen inputs to Florida Bay: the importance of the Everglades watershed. Estuaries 22: 398-416

Sklar F, McVoy C, Vanzee D, Gawlik E, Tarboton K, Rudnick D, Miao S (2001) The effects of altered hydrology on the ecology of the Everglades. In: Porter JW, 
Porter KG (eds) The Everglades, Florida Bay, and coral reefs of the Florida Keys: an ecosystem sourcebook. CRC Press, Boca Raton, Florida, pp 39-82

Solórzano L, Sharp JH (1980) Determination of total dissolved phosphorus and particulate phosphorus in natural waters. Limnology and Oceanography 25:754758

Stow CA, Roessler C, Borsuk ME, Bowen JD, Reckhow KH (2003) Comparison of estuarine water quality models for total maximum daily load development in Neuse River Estuary. Journal of Water Resources Planning and Management 129:307-314

Sutula MA, Perez BC, Reyes E, Childers DL, Davis S, Day JW JR, Rudnick D, Sklar F (2003) Factors affecting spatial and temporal variability in material exchange between the southern Everglades wetlands and Florida Bay (USA). Estuarine, Coastal and Shelf Science 57:757-781

USACE. 2011. Central and southern Florida project comprehensive Everglades restoration plan C-111 spreader canal western project: final integrated project implementation report and environmental impact statement

Wachnicka A, Gaiser E, Wingard I, Briceño H, Harlem P (2013) Impact of late Holocene climate variability and anthropogenic activities on Biscayne Bay (Florida, U.S.A.): evidence from diatoms. Palaeogeography, Palaeoclimatology, Palaeoecology $371: 80-92$

Woods J, Zucker M (2007) Estuarine response in northeastern Florida Bay to major hurricanes in 2005. In: Farris et al (eds) Science and the storms: the USGS response to the hurricanes of 2005, USGS Circular 1306:184-191 


\section{List of Figures}

Figure 1: Map showing Florida Bay and location of water quality sampling sites considered in this analysis. C-111 canal basin and Taylor Slough are delineated. Sites in map are identified as follows TRup: Taylor River upstream, TRm: Taylor River mouth

Figure 2: Box and whisker plots of (a) daily discharge $\left(\mathrm{m}^{3} \mathrm{~s}^{-1} ; \mathrm{NAVD88}\right)$, (b) mean daily stage $(\mathrm{m}),(\mathrm{c})$ mean daily salinity (ppt), and $(\mathrm{d})$ tri-daily TP $(\mu \mathrm{M})$ by month at Taylor River mouth during the period of record. The center horizontal line of the box is the median of the data, the top and bottom of the box are the 25th and $75^{\text {th }}$ percentiles (quartiles), and the ends of the whiskers are the 5th and 95th percentiles. The notch in the box is the $95 \%$ confidence interval of the median. When notches between boxes do not overlap, the medians are considered significantly different. Outliers ( $<5$ th and $>95$ th percentiles) were excluded from the graphs to reduce visual compression.

Figure 3: Temporal time series and their respective standardized cusum charts for Rainfall at NOAA's Everglades Station (N 2551'; W81 ${ }^{\circ} 23^{\prime}$ ), and Taylor River mouth station discharge, salinity, TN, TP, and TN:TP. General cup-shaped chart (i.e. salinity) indicates increasing secular trend, while dome-shaped line-plot indicates declining secular trend (i.e. TN:TP). Note the time-series and cusum seasonality in discharge and salinity, as well as cusum changes in salinity, TN, TP, and TN:TP around 2004-2005 in association with those strong hurricane seasons.

Figure 4: Discharge gradient cusum charts for salinity, TN, TP, and TN:TP in Taylor upstream (a-d) and Taylor mouth (e-h), respectively. TP in Taylor upstream and salinity in both stations display declining secular trends with discharge, while TN:TP trend in upstream station increases. TP and TN:TP in Taylor mouth and $\mathrm{TN}$ in both stations display non linear responses to discharge. Peak-shaped inflexion points highlight largest changes from above-average to below-average values, while $\mathrm{V}$-shaped inflexion points indicate the opposite. 


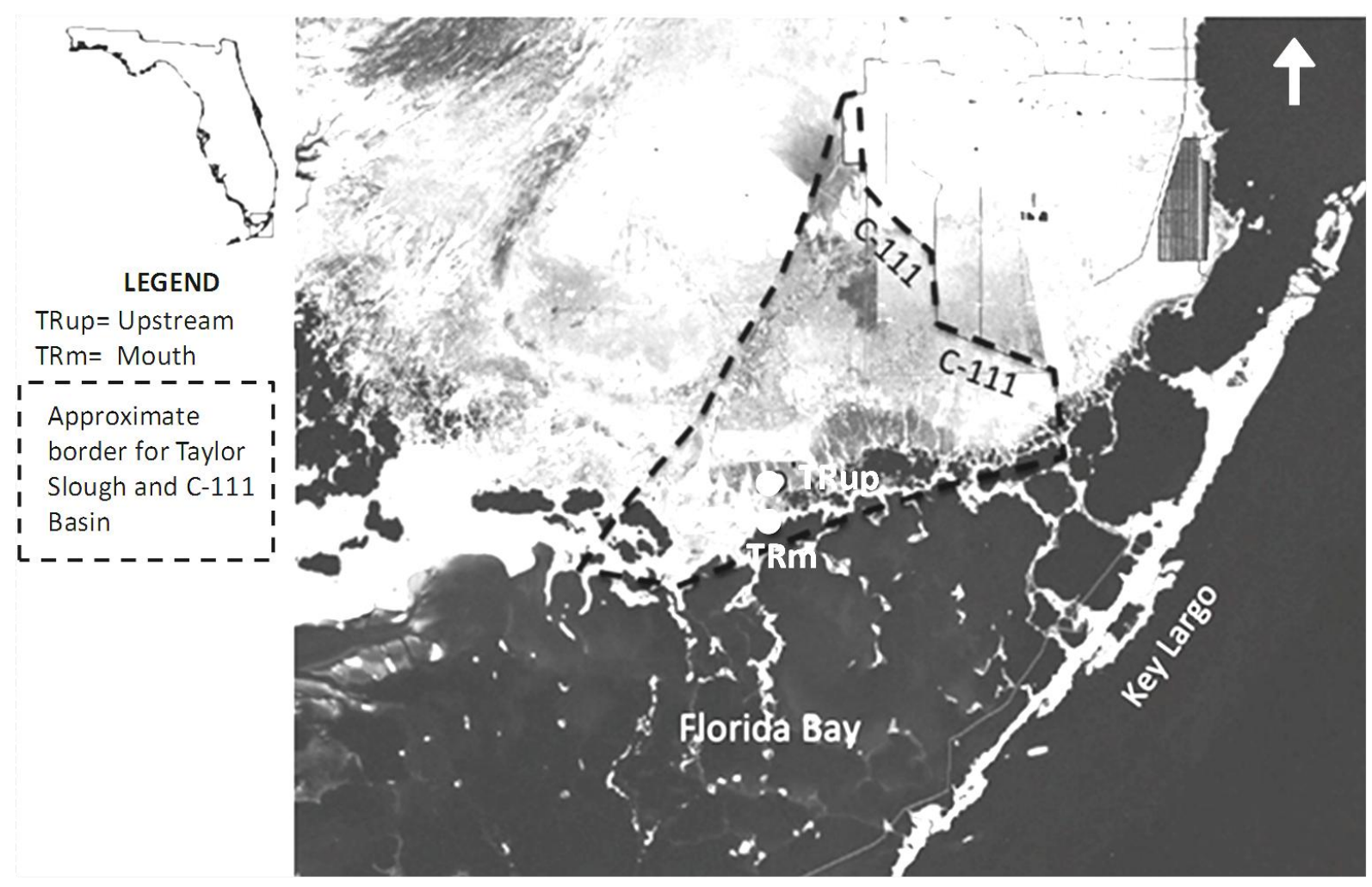



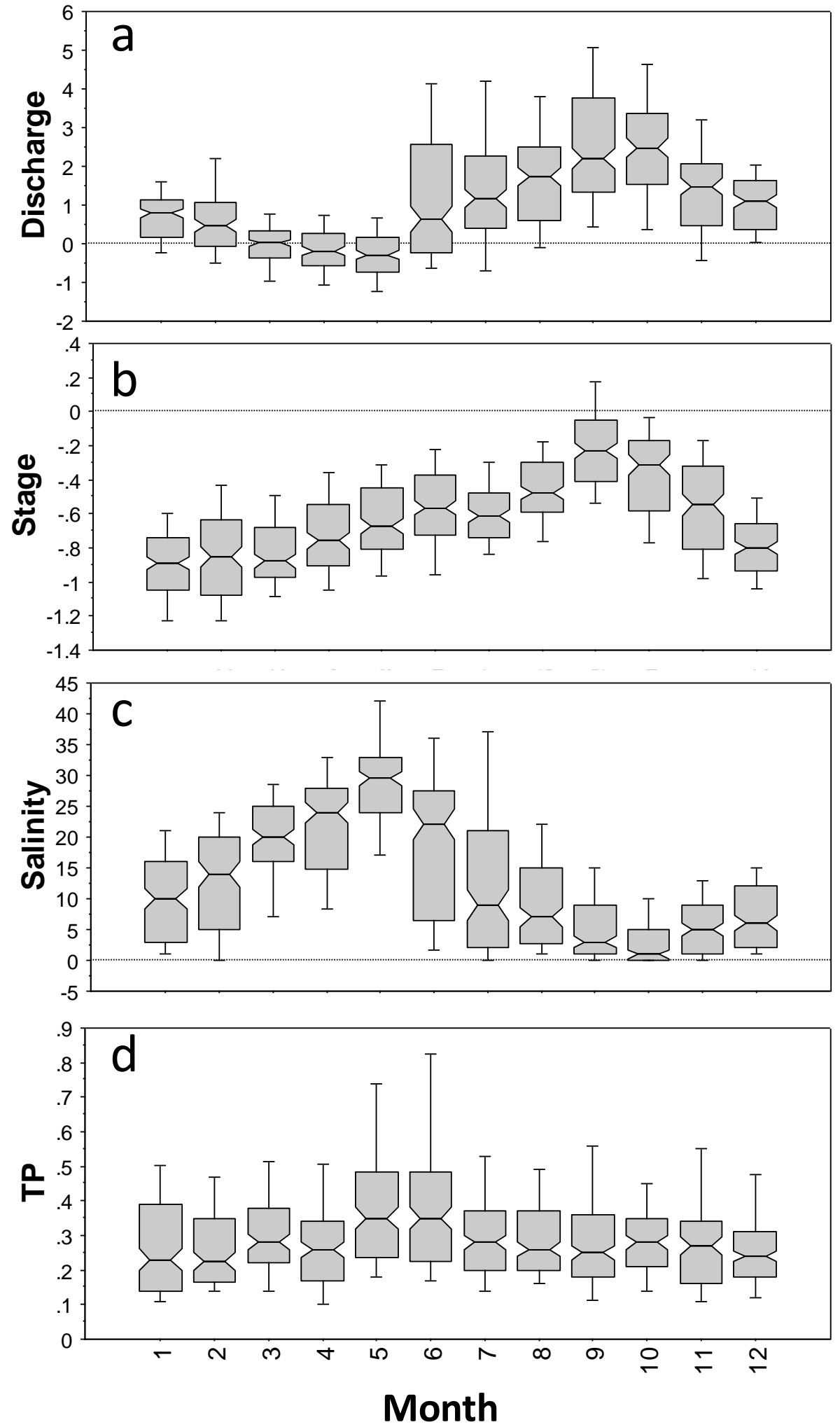


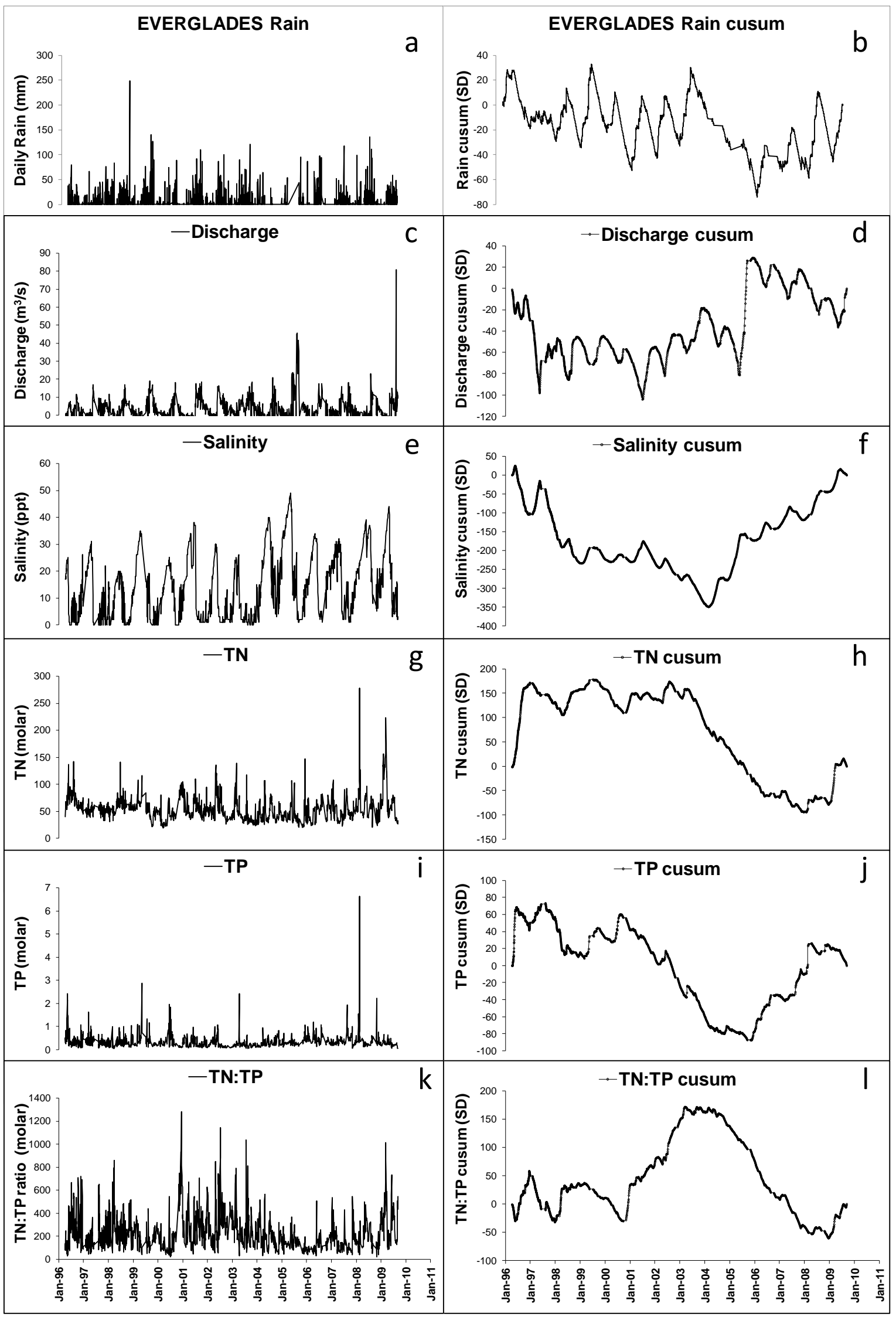




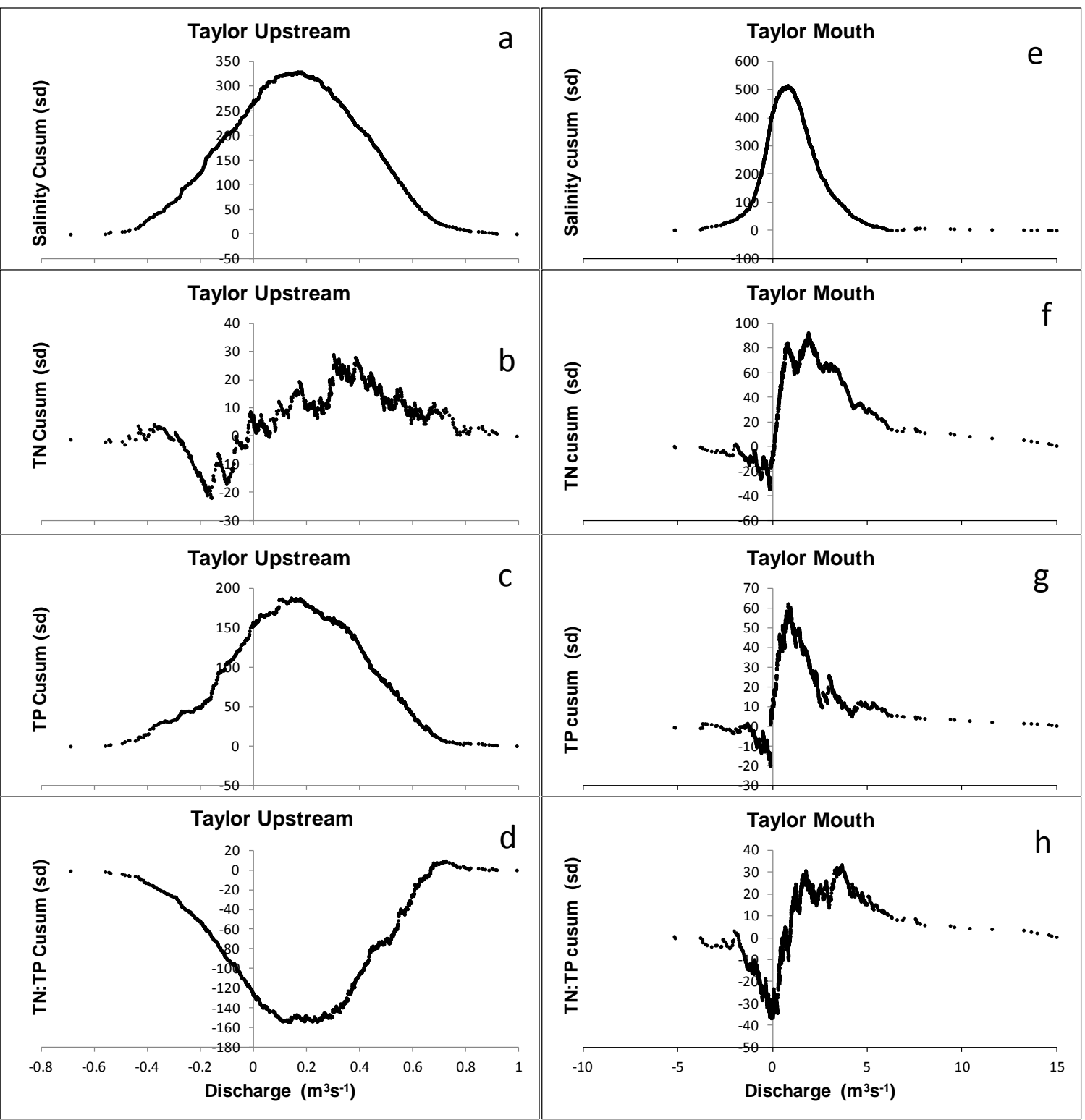

2 
1 Table 1: Basic statistics for relevant parameters at Taylor Mouth and Upstrean Taylor 2 Stations. Units: TP and TN in UM; TN:TP in molar ratio; Salinity in ppt; Stage in m; and 3 Discharge in cfs.

4

\begin{tabular}{|rcccccc|}
\hline UPSTREAM TAYLOR & TP & TN & TN:TP & Salinity & Stage & Discharge \\
Average & 0.36 & 49.01 & 209.77 & 8.51 & -0.33 & 9.20 \\
Stdev & 0.29 & 23.49 & 175.45 & 11.94 & 0.44 & 10.53 \\
Median & 0.28 & 41.95 & 152.72 & 2.00 & -0.38 & 10.78 \\
Max & 2.76 & 185.68 & 1304.80 & 49.00 & 1.47 & 35.05 \\
Min & 0.04 & 16.16 & 14.82 & 0.00 & -1.26 & -24.38 \\
\hline
\end{tabular}

\begin{tabular}{r|rcccccc|}
\hline TAYLOR MOUTH & TP & TN & TN:TP & Salinity & Stage & Discharge \\
& Average & 0.32 & 51.48 & 225.14 & 15.56 & -0.59 & 44.39 \\
Stdev & 0.30 & 24.09 & 161.80 & 12.36 & 0.37 & 81.30 \\
& Median & 0.25 & 46.24 & 174.19 & 14.00 & -0.59 & 27.95 \\
& Max & 6.64 & 278.30 & 1284.89 & 49.00 & 0.88 & 935.94 \\
& Min & 0.05 & 19.48 & 21.42 & 0.00 & -1.65 & -183.51 \\
\hline
\end{tabular}

6

7 Table 2: Slopes of Line of Ordinary Regression as estimate of secular trends along 8 discharge gradients

\begin{tabular}{|lrrrrrr|}
\cline { 2 - 7 } \multicolumn{1}{l|}{} & TP & TN & TN:TP & Stage & Salinity \\
\hline Upstream Taylor & & & & & & \\
& slope & -0.0096 & -0.0491 & 4.8889 & 0.0061 & -0.7317 \\
& $\mathrm{p}$ & $<.0001$ & 0.4691 & $<.0001$ & $<.0001$ & $<.0001$ \\
\hline Taylor Mouth & & & & & & \\
& slope & -0.0002 & -0.0323 & -0.0661 & 0.0007 & -0.0797 \\
& $\mathrm{p}$ & 0.0582 & $<.0001$ & 0.1955 & $<.0001$ & $<.0001$ \\
& & & & & & \\
\hline
\end{tabular}

